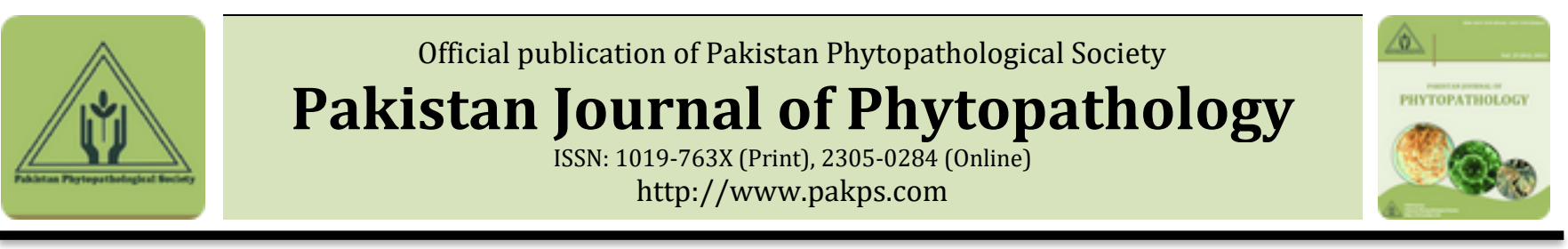

\title{
EVALUATION OF DIFFERENT PLANT EXTRACTS IN REDUCING BEMISIA TABACI AND URDBEAN LEAF CRINKLE VIRUS (ULCV) DISEASE INCIDENCE ON GREENGRAM
}

\author{
aTahira Saleem, a Muhammad A. Khan, aAbdul Rehman, bAzher Mustafa \\ a Department of Plant Pathology, University of Agriculture, Faisalabad, Pakistan. \\ b Plant Virology, Ayub Agriculture Research Institute, Faisalabad, Pakistan.
}

\begin{abstract}
A B S T R A C T
ULCVD is the most prevailing threat to mungbean and urdbean worldwide. ULCV is a seed born virus and also transmit through insect vectors. Among all vectors, whitefly (Bemisia tabaci) is the most devastating vector in causing this disease. Different mungbean genotypes were sown under natural conditions. The efficacy of different plant extracts (garlic, bougainvillea, onion) against whitefly population and ULCV was determined. Results showed that plant extracts can be useful to manage the disease and vector populations. Garlic extract was found effective and minimum disease severity of $10.48 \%$ with least whitefly population 1.27 , was seen on plants that were sprayed with garlic extract followed by bougainvillea and onion.
\end{abstract}

Keywords: ULCVD, Mungbean, Whitefly, Plant extracts.

\section{INTRODUCTION}

Greengram or mungbean (Vigna radiata L.) belongs to family Fabaceae, native to India. Being a rich source of protein, it is an important short duration crop in humid and sub-humid regions of the world (Akhtar and Haq, 2003). Anjum et al. (2006) predicted that mungbean needs less water as compared to summer crops. In Pakistan mungbean is cultivated over an area of 137 thousand hectares and annual production is 77.1 thousand metric tons (GOP, 2011). Under field conditions, eight viruses attack on mungbean (Nene, 1972). Several biotic and abiotic factors are responsible for the less yield of the crop. When mungbean is grown under field conditions, it is prone to numerous viral diseases; the most important are urdbean leaf crinkle virus (ULCV) and bean yellow mosaic virus (BYMV) (Bashir et al., 2006).

Urdbean leaf crinkle disease is a devastating disease of greengram (Vigna radiata) and blackgram (Vigna mungo

\section{Submitted: May 17, 2017}

Revised: July 12, 2017

Accepted for Publication: May 02, 2018

* Corresponding Author:

Email: tahira.saleem22@gmail.com

(C) 2017 Pak. J. Phytopathol. All rights reserved.
Hepper) caused by urdbean leaf crinkle virus (ULCV) (Bashir \& Malik, 1988). ULCV is known to spread through seeds and insects (Nene, 1972; Kadian, 1980). Whitefly is also a major vector of ULCV (Binyamin et al., 2011). Out of 254 lines, 247 lines were recorded as highly susceptible mungbean lines against MYMV as a result of whitefly attack (Nadeem et al., 2006). Primary infection occurs through seed (Beniwal et al., 1980 ). With the time and space vector movement also varies accordingly (Taylor, 1984). Virus causes heavy losses at an early stage of the plant according to research done by Bashir et al. (1991). In Pakistan, ULCVD has been a devastating disease because of its high incidence from 40 to $100 \%$ recorded in the field and yield losses have been recorded up to $70 \%$ (Zeeshan et al., 2014)). The first 3-4 weeks are important in spread of leaf crinkle disease (Ashfaq et al., 2008).

Various approaches have been done in reducing the disease and vector population. But, plant extracts are mainly effective because of eco-friendly nature. Leaf extracts have some inhibitory role against the disease. This study was conducted to evaluate various plant extracts for the management of ULCVD and whitefly population. 


\section{MATERIALS AND METHODS}

Mungbean varieties/lines were sown in the Research Area of Plant Pathology, University of Agriculture, Faisalabad on $15^{\text {th }}$ March, 2017. Seeds were planted on the ridges, plant to plant and row to row spacing $15 \mathrm{~cm}$ and $30 \mathrm{~cm}$, respectively in RCBD. The crop was irrigated at 15 days interval. All the conventional agronomic practices were followed to keep the crop in a good growing condition except spraying of any pesticides. Insect traps consisting of plastics cards $(1 \times 1.5$ feet) impregnated with Vaseline fastened with a hanger were placed in the field at four sides. Data of vector population were taken by counting the number of whiteflies on yellow boards and on the leaves of the plants. Yellow water traps consisting of yellow iron trays $(1 \times 2.5$ feet $)$ were also placed at two sites of mungbean field and number of whiteflies trapped in these trays was recorded on weekly basis.

The disease incidence of ULCV infected plants showing extreme crinkling were evaluated by visual inspection at every line in every plot (Zeshan et al., 2014). The disease incidence and whitefly population were recorded. Monitoring of infected plants was executed on weekly basis starting from emergence date till the end of the season. ULCV was confirmed by the method of sap inoculation as described by (Phullaiah et al., 1998). Data of diseased plants were recorded after 7 days of sap ULCV.

For management of mungbean varieties/lines against ULCV disease, plant extracts of Bougainvillea spectabilis, Allium cepa (onion) and Allium sativum (garlic) @2\% concentration, were used. $2 \mathrm{~g}$ extracts was dissolved in $1000 \mathrm{ml}$ distilled water to prepare stock solution. Material was then shaken in an orbital shaker for $6 \mathrm{~h}$ at $25^{\circ} \mathrm{C}$. After that, for $2 \%, 2 \mathrm{ml}$ was taken from stock solution and dissolved in $98 \mathrm{ml}$ distilled water. Plant extracts were sprayed thrice on greengram sown under natural conditions. The experiment was conducted in an area of Plant Pathology, University of Agriculture Faisalabad in Randomized Complete Block
Design (RCBD). Progression of ULCV was recorded at weekly basis; disease incidence was calculated by counting the total number of healthy and diseased plants and taken their percent. Whitefly population was calculated by calculating no. of whiteflies in upper, middle and lower layer before and after $48 \mathrm{~h}$ when plant extracts were applied. The extent of ULCV disease in all mungbean accessions was noted at one week interval for five weeks.

The data was analyzed statistically by ANOVA. Least Significant Difference (LSD) test was used for statistical comparison among treatments (Steel et al., 1997).

\section{RESULTS AND DISCUSSION}

Analysis of variance table showed that there was a significant variation within the varieties and also within the extracts. Two way interactions or treatment and variety showed highly significant results (Table 1). It was indicated that in case of garlic with $2 \%$ concentration, disease incidence was $23.8 \%, 19.86 \%, 15.01 \%$ and $10.48 \%$ on 15033,15405 , M07007 and on M-07002, respectively. Similarly by the extract of bougainvillea at $2 \%$ concentration disease incidence was $29.29 \%, 26.21 \%, 16.14 \%$ and $14.19 \%$ on 15033,15405 , M07007 and on M-07002, respectively. And onion extract showed disease incidence of $33.48 \%, 29.27 \%, 25.47 \%$ and $20.97 \%$ on 15033,15405 , M-07007 and on M-07002, respectively. Moreover, in case of control maximum disease incidence was recorded i.e. $47.19 \%, 44.2 \%, 40 \%$ and $38 \%$ on 15033, 15405, M-07007 and on M-07002, respectively (Table 2).

Control showed maximum disease incidence as reported by various scientists like Reddy et al. (2006), Karthikeyan et al. (2008) and Thirumalaisamy et al. (2003). According to them, anti-viral properties of plant extracts exhibited inhibition in disease incidence of ULCVD.

In case of whitefly, garlic with $2 \%$ concentration showed minimum vector population i.e. $3.10,2.44,1.85$ and 1.27 on 15033, 15405, M-07007 and on M-07002, respectively.

Table 1. Analysis of variance table for plant extracts against ULCV disease incidence

\begin{tabular}{|c|c|c|c|c|}
\hline Source of variation & D.F & Sum of squares & Mean squares & F-value \\
\hline Block & 2 & 3.7 & 1.87 & $0.72^{\mathrm{NS}}$ \\
\hline Treatment & 3 & 13250.4 & 4416.8 & $1697.69^{* *}$ \\
\hline Variety & 3 & 3366.3 & 1122.1 & $431.30^{* *}$ \\
\hline Treat*Variety & 9 & 218.7 & 24.3 & $9.34^{* *}$ \\
\hline Treat*Spray & 6 & 27.5 & 4.59 & $1.76^{\mathrm{NS}}$ \\
\hline Error & 36 & 93.7 & 2.6 & \\
\hline Total & 85 & 17143.3 & & \\
\hline
\end{tabular}


Table 2. Treatment $x$ Variety Interaction mean $\pm S E$ for Disease incidence

\begin{tabular}{|c|c|c|c|c|c|}
\hline \multirow{2}{*}{ Treatments } & \multicolumn{4}{|c|}{ Varieties } & \multirow{2}{*}{ Mean } \\
\hline & 15033 & 15405 & M-07007 & M-07002 & \\
\hline Garlic & $23.81 \mathrm{~h}$ & $19.86 \mathrm{i}$ & $15.08 \mathrm{jk}$ & $10.48 \mathrm{l}$ & $17.31 \mathrm{D}$ \\
\hline Bougainvillea spectabilis & $29.29 \mathrm{f}$ & $26.21 \mathrm{~g}$ & $16.14 \mathrm{j}$ & $14.19 \mathrm{k}$ & $21.46 \mathrm{C}$ \\
\hline Onion & $33.48 \mathrm{e}$ & $29.27 \mathrm{f}$ & $25.47 \mathrm{~g}$ & $20.97 \mathrm{i}$ & $27.29 \mathrm{~B}$ \\
\hline Control & $47.19 \mathrm{a}$ & $44.2 \mathrm{~b}$ & $40.0 \mathrm{c}$ & $38 \mathrm{~d}$ & $42.35 \mathrm{~A}$ \\
\hline Mean & $35 \mathrm{~A}$ & $30 \mathrm{~B}$ & $24.17 \mathrm{C}$ & $20.91 \mathrm{C}$ & \\
\hline
\end{tabular}

Means sharing similar letter in a row or in a column are statistically non-significant $(\mathrm{P}>0.05)$. Small letters represent comparison among interaction means and capital letters are used for overall mean.

LSD value for interaction $(5 \%)=1.542$

Table 3. Treatment $x$ Variety Interaction mean \pm SE for whitefly population

\begin{tabular}{|c|c|c|c|c|c|}
\hline \multirow{2}{*}{ Treatments } & \multicolumn{3}{|c|}{ Varieties } & \multirow[b]{2}{*}{ M-07002 } & \multirow{2}{*}{ Mean } \\
\hline & 15033 & 15405 & M-07007 & & \\
\hline Garlic & $3.11 \mathrm{f}$ & $2.44 \mathrm{gh}$ & $1.85 \mathrm{ij}$ & $1.27 \mathrm{k}$ & $2.16 \mathrm{D}$ \\
\hline Bougainvillea spectabilis & $4.07 \mathrm{~d}$ & $2.67 \mathrm{~g}$ & 2.11hi & $1.68 \mathrm{j}$ & $2.63 \mathrm{C}$ \\
\hline Onion & $5.5 \mathrm{~d}$ & $3.51 \mathrm{e}$ & $2.17 \mathrm{hi}$ & $1.62 \mathrm{j}$ & $3.2 \mathrm{~B}$ \\
\hline Control & $6.53 a$ & $5.04 c$ & $4.83 \mathrm{de}$ & $2.28 \mathrm{~h}$ & $4.67 \mathrm{~A}$ \\
\hline Mean & $4.80 \mathrm{~A}$ & $3.42 \mathrm{~B}$ & $2.74 \mathrm{C}$ & $1.72 \mathrm{D}$ & \\
\hline
\end{tabular}

LSD value for interaction $=5 \%=0.3482$

Similarly by the extract of Bougainvillea at $2 \%$ concentration whitefly population was $4.07,2.67,2.11$ and 1.68 on 15033, 15405, M-07007 and on M-07002, respectively. In case of onion extract at $2 \%$ concentration, the whitefly population was maximum i.e. 5.5, 3.51, 2.17 and 1.62 on 15033, 15405, M-07007 and on M-07002, respectively. Control had maximum whitefly population i.e. $6.53,5.04,4.83$ and 2.28 on 15033, 15405, M-07007 and on M-07002, respectively. (Table 3).

On M-07002, minimum whitefly population and disease incidence was found i.e. 1.27 and $10.48 \%$, respectively. While, 15033 was found highly susceptible and showed maximum disease incidence as well as vector population. In this study, it was found that plant extracts have a significant role as they reduced the whitefly population and ULCV disease incidence up to significant level. As, garlic have the properties of authorizing immune system anti- tumor and antioxidant effects and its extract is used against viral infections (Goncagul and Ayaz, 2010). Onion shows inhibitory effect on virus because of two most important flavonoids (quercetin and kaempferol) (Duh et al., 2008). Leaves of bougainvillea cause stimulation of the assembly of phenolics and as a result the activities of peroxidase, polyphenol oxidase and phenylalanine ammonialyase enhanced. (Karthikeyan et al., 2009).

\section{CONCLUSION}

The low yield potential, susceptibility to diseases, insect pests attack and sensitivity to environmental fluctuations contribute towards yield instability. Plant extracts are economical and eco-friendly. Among three extracts, garlic extract gave best results for reducing vector population as well as disease incidence. While bougainvillea gave good results and onion showed satisfactory results. As ULCVD is a seed born virus so the use of diseased free seeds is a best way to reduce the viral infection, after that, plant extracts are the economical way to control vector population and disease incidence.

\section{REFERENCES}

Akhtar, K. P. and M. Ahsanul Haq. 2003. Standardization of a Graft Inoculation Method for the Screening of Mungbean Germplasm against Mungbean yellow mosaic virus (MYMV). The Plant Pathology Journal, 19: 257-259.

Anjum, M., Z. Ahmed and C. A. Rauf. 2006. Effect of Rhizobium inoculation and nitrogen fertilizer on yield and yield components of mungbean. International Journal of Agriculture and Biology (Pakistan).

Ashfaq, M., M. A. Khan and N. Javed. 2008. Characterization of environmental factors conducive for Urdbean leaf crinkle (ULCV) disease development. Pak. J. Bot, 40: 2645-2653.

Bashir, M. and B. A. Malik. 1988. Diseases of major pulse crops in Pakistan-a review. Tropical Pest 
Management, 34: 309-314.

Bashir, M., S. Mughal and B. Malik. 1991. Assessment of yield losses due to leaf crinkle virus in urdbean (Vigna mungo (L) Hepper). Pak. J. Bot, 23: 140142.

Bashir, M., Z. Ahmad and S. Mansoor. 2006. Occurrence and distribution of viral diseases of mungbean and mashbean in Punjab, Pakistan. Pakistan Journal of Botany, 38: 1341.

Beniwal, S. and N. Bharathan. 1980. Beetle transmission of urdbean leaf crinkle virus. Indian Phytopathology, 33: 600-601.

Binyamin, R., M. A. Khan, N. Ahmad and A. Safdar. 2011. Relationship of epidemiological factors with urdbean leaf crinkle virus disease and its management using plant extracts. International Journal of Agriculture and Biology, 13.

Duh, P., W. Hsiao and B. Wang. 2008. An aqueous extract of Welsh onion green leaves increase ABCA1 and SR-BI expression in macrophage RAW 264.7 cells. Food Chemistry, 107: 1029-1038.

Goncagul, G. and E. Ayaz. 2010. Antimicrobial Effect of Garlic (Allium sativum). Recent Patents on AntiInfective Drug Discovery, 5: 91-93.

GOP. 2010-11. Economic Survey of Pakistan 2010-11. Ministry of Food and Agriculture, Govt. of Pak. pp. 19.

Kadian, O. P. 1980. Studies on Leaf Crinkle Disease of Urd Bean (Vigna Mungo (L.) Hepper)/mung Bean (Vigna Radiata (L.) Wilczek) and Its Control. Plant Pathology, CCSHAU, Hisar.

Karthikeyan, G., S. Doraisamy, R. Rabindran and T. Ganapathy. 2009. Evaluation of antiviral principles for the induction of systemic resistance in blackgram (Vigna mungo) against Urdbean Leaf Crinkle Virus. Archives Of Phytopathology And Plant Protection, 42: 1172-1186.

Nadeem, S., S.M. Mughal, K. Farooq and M. Bashir. 2006. Evaluation of mungbean germplasm for resistance against mungbean yellow mosaic begomovirus. Pak. J. Bot. 38(2): 449-457.

Nene, Y. 1972. A survey of viral diseases of pulse crops in Uttar Pradesh. A survey of viral diseases of pulse crops in Uttar Pradesh.

Pullaiah, N., T. B. Reddy, G. Moses, B. Reddy and D. R. Reddy. 1998. Inheritance of resistance to yellow vein mosaic virus in okra (Abelmoschus esculentus (L.) Moench). The Indian Journal of Genetics and Plant Breeding, 58: 349-352.

Reddy, R.C., V. A. Tonapi, S. Varanavasiappan, S. S. Navi and R. Jayarajan. 2006. Management Of Urd Bean Leaf Crinkle Virus In Urd Bean (Vigna Mungo L. Hepper). International Journal of Agriculture Sciences, 2: 22-28.

Steel, R. G., J. H. Torrie and D. A. Dickey. 1997. Principles and procedures of statistics: A biological approach. McGraw-Hill.

Taylor, L. R. 1984. Assessing and Interpreting the Spatial Distributions of Insect Populations. Annual Review of Entomology, 29: 321-357.

Thirumalaisamy, P., Y. Rathi and H. Tripathi. 2012. Screening of some plant extracts inhibitory to urdbean leaf crinkle virus. Indian Phytopathology.

Zeshan, M. A., S. Ali and M. A. Khan. 2014. Phenotypic Response of Mungbean Germplasm Against Urdbean Leaf Crinkle Virus Disease. BIOLOGIA (Pakistan), 60: 309-312. 